\title{
Study on Temporal Variation of Physico-chemical Parameters of Buriganga River Water through GIS (Geographical Information System) Technology
}

\author{
Mohammad Moniruzzaman*a, Syed Fazle Elahi', Md. Abu Anis Jahangir \\ ${ }^{a}$ BCSIR Laboratories, Dhaka. Dr. Qudrat-I-Khuda Road, Dhanmondi, Dhaka-1205. ${ }^{b}$ Department of Soil, Water and \\ Environment, University of Dhaka, Dhaka-1000, Bangladesh.
}

\begin{abstract}
Now a days, Buriganga is one of the most polluted rivers in Bangladesh. Most of the industries and factories of Dhaka are situated on the banks of the Buriganga or very close to the river system. Substantial part of urban sewage of the Dhaka city is also thrown in the Buriganga river. A study was conducted to determine the pollution level of water of Buriganga river. Field investigation was started from June 2004 and Sample collection was conducted six times at an interval of two months up to April, 2005. Different water quality parameters such as $\mathrm{pH}, \mathrm{EC}$, TDS, DO, Cations $\left(\mathrm{Na}^{+}, \mathrm{K}^{+}, \mathrm{Ca}^{2+}, \mathrm{Mg}^{2+}, \mathrm{NH}^{+}\right)$and anions $\left(\mathrm{HCO}_{3}{ }^{-}, \mathrm{Cl}^{-}, \mathrm{SO}_{4}{ }^{2-}, \mathrm{PO}_{4}{ }^{3-}, \mathrm{NO}_{3}{ }^{-}\right)$were examined for water of each sampling points to monitor the level of these parameters where it exceed or within the permissible limit. Present investigation suggested that, Dissolved Oxygen (DO) concentration of water of Buriganga river was very low particularly in dry season (2-3 mg/l). Ammonium $\left(\mathrm{NH}_{4}{ }^{+}\right)$and Nitrate $\left(\mathrm{NO}_{3}{ }^{-}\right)$concentration near Hazaribagh, Sadarghat, Zinzira, Lalbagh, Kotouali and Shutrapur area were very high, which crossed the maximum permissible limit. In dry season the level of pollution was much high than in wet season. That indicates the water of Buriganga was not safe for drinking purposes, irrigation, fisheries, recreational activities and various industrial uses for most of the times of year.
\end{abstract}

Key words: Buriganga river, GIS technology, Temporal variation

\section{Introduction}

Although Bangladesh is predominantly a plain surface, it is criss-crossed by a very high density river system. Bangladesh depends on its river system for such purposes as agriculture, navigation, sanitation, drainage, forestry, fishery and control of salinity. They also play significant roles in settlement patterns, domestic water supply and communications and, indirectly, in sanitation and health. But some rivers have become biologically and hydrologically dead because of the indiscriminate dumping of domestic and industrial wastes, encroachment by unscrupulous people. (Ahmed et al, 2000).

The river Buriganga flowing through the heart of the Dhaka city carry heavy loads of industrial wastes. These industrial wastes are discharged in to the river especially effluents from tanneries located in Hazaribagh area. The Department of Environment (DoE) identified 249 factories along the river Buriganga (Sarker, 2005).

Most of the industries and factories of Dhaka are situated on the banks of the Buriganga or very close to the river system.

*Corresponding Author, Email: monirbcsir@gmail.com
The industries mainly textiles and garments-cum dying factories mushroomed in this area without setting up waste treatment units during the past decade. The urban sewage of the Dhaka city are also thrown in the Buriganga river, So, huge amount of effluents and solid wastes are adding with the river water and sediments. The Buriganga river is apprehended to be one of the polluted part of the river system of Bangladesh (Sarker, 2005).

So it was very important to survey the water quality parameters of Buriganga river to investigated the source of pollutants and quantified its level of pollution.

The principal objectives of the present research involve the following points:

a) To find out the spatial distribution of pollutants in water of Buriganga river.

b) To evaluate the seasonal variation of these pollutants.

c) To recommended the potential uses of water of Buriganga river. 


\section{Materials and Method}

The Buriganga River encompasses the south-western periphery of Dhaka City. It originates from Dhaleswari from north of Dhaka and meets it again south of Dhaka City. The Buriganga River has been selected as the case study for this research. Water sampling was started from the point,

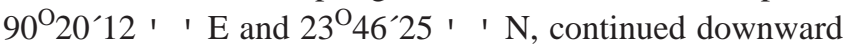
at an interval of $1 \mathrm{~km}$ for $26 \mathrm{~km}$ (Map.1). Total number of samples collected during each sampling time was 27. Location was confirmed by GPS (Model: Magellan GPS 320). Water samples were collected at each point with water sampler (Model: UWITEC, A-3510) in the midstream at a depth of 1 to 2 meters to avoid the interference of the floating substances. Sample collection was conducted six times at an interval of two months from June, 2004 to April, 2005. The high-density 1-liter PVC bottles were used for sample collection and

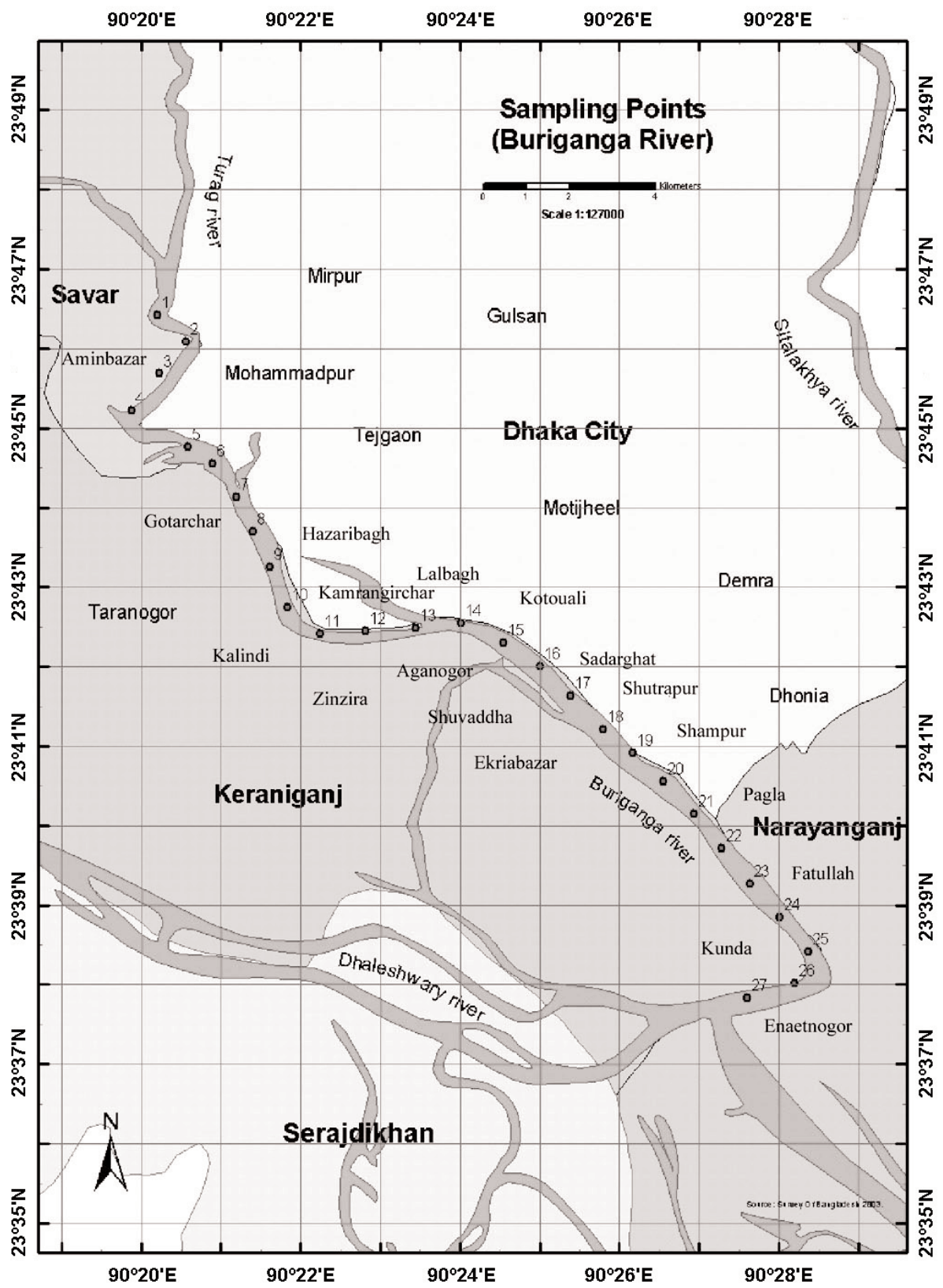

Map. 1. Sampling point in Buriganga river 
The temperature of the water samples was measured immediately in the river by a mercury thermometer of 0 to $50^{\circ} \mathrm{C}$ range and with $0.2^{\mathrm{O}} \mathrm{C}$ least count (Gupta, 2000). Water $\mathrm{pH}$ was determined by glass electrode using $\mathrm{pH}$ meter (Model: Jenway instrument, pH meter 3305) (Jackson, 1967). The Electric conductivity (EC) of water samples was directly determined in the river by EC meter (Model: HANNA HI8633) in $\mu \mathrm{s} / \mathrm{cm}$ (Jackson, 1967). A rapid determination of total dissolved solids (TDS) of water samples was determined in the field by TDS meter (Model: Mettler-Toledo Ag, CH-8603) (Todd, 1980). Dissolved oxygen of water samples was determined in the field by DO meter (Model: MettlerToledo Ag, CH-8603).

The ammonium- $\mathrm{N}\left(\mathrm{NH}_{4}-\mathrm{N}\right)$ and Nitrate- $\mathrm{N}\left(\mathrm{NO}_{3}-\mathrm{N}\right)$ were determined by micro Kjeldahl's distillation method (Jackson, 1967). Sodium (Na) and potassium (K) of water samples were determined by flame emission spectrophotometry method (Model: Jencons, PEP7) (Jackson, 1967). The calcium and magnesium of the water samples was determined by EDTA complexometric titration method (Lanyon and Heald, 1982).The chloride of the water samples was determined by Mhor volumetric method (Jackson, 1967). The bicarbonate and carbonate content of the water samples were determined volumetrically (Jackson, 1967). The sulphate content of water samples was determined by turbidimetric method (Hunt, 1981). Phosphate content of the water samples was determined by ascorbic acid blue color method (Murphy and Riley, 1962).

The chemical analyses were carried out in BCSIR laboratories, Dhaka and Department of Soil, Water and Environment, University of Dhaka.

\section{Results and Discussion}

\section{Physico-Chemical Parameters}

Temperature of river water was low from December to February around $18^{\circ} \mathrm{C}$ to $21^{\circ} \mathrm{C}$ and the lowest average temperature of water found during the month of December $\left(18^{\mathrm{O}} \mathrm{C}\right)$. Again temperature of water was high from April to August with average value in the range of $32^{\circ} \mathrm{C}$ to $35^{\circ} \mathrm{C}$ and the highest average temperature of water was recorded in the month of April $\left(35^{\circ} \mathrm{C}\right)$ (Fig 1).

In the study area the $\mathrm{pH}$ of water collected at different points and at different times of year ranged from 7.1 to 7.6. The $\mathrm{pH}$ of water was slightly high from December to April (7.4 to 7.6) and the highest average $\mathrm{pH}$ value found during the month of April ( $\mathrm{pH}=7.6)$. This is due to high base satura

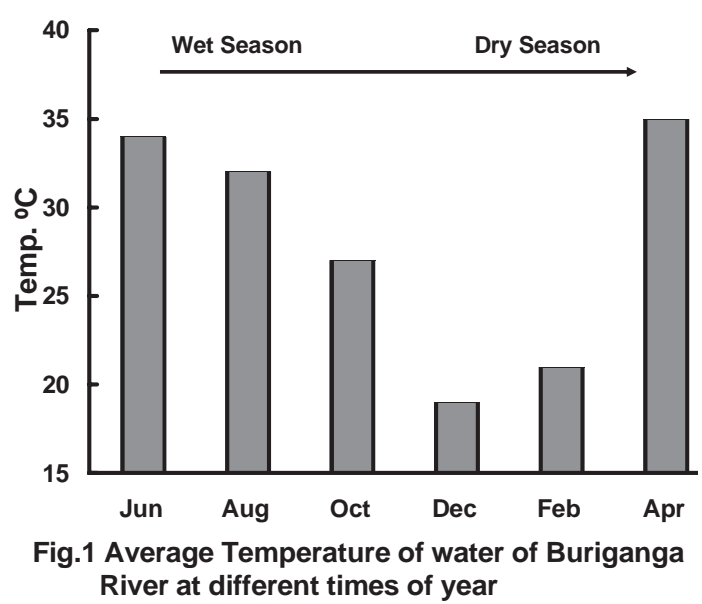

tions with low volume of water during dry season. On the other hand, the $\mathrm{pH}$ of water was slightly low during wet season from June to October (7.3 to 7.4) due to dilution effect and the lowest average $\mathrm{pH}$ value found during the month of August (pH = 7.3) (Fig. 2).

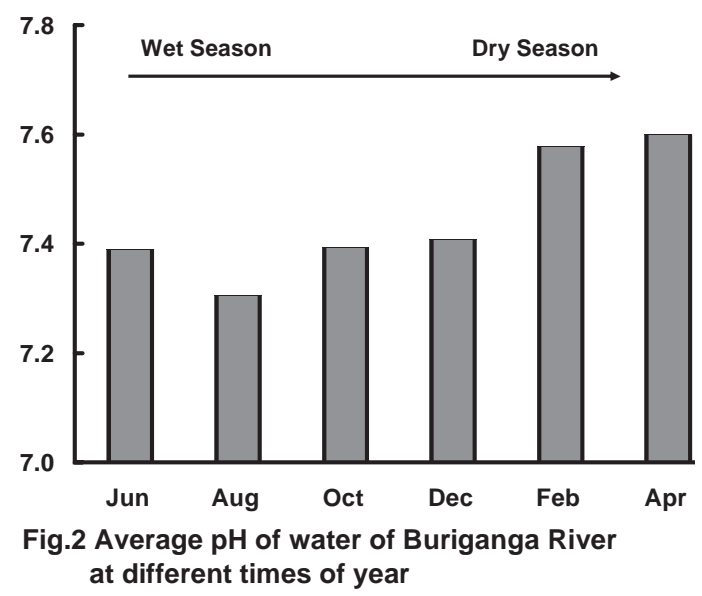

But all these $\mathrm{pH}$ values at different times of year were within the permissible limit (Table I).

Electrical conductivity is an estimate of the total amount of dissolved ions in the water. EC of water of Buriganga river were with in the range from 90 to $1150 \mu \mathrm{S} / \mathrm{cm}$. The EC value of water was comparatively high from February to April (774 to $917 \mu \mathrm{S} / \mathrm{cm}$ ) and the highest average EC value of water recorded during the month of April $(917 \mu \mathrm{S} / \mathrm{cm})$ (Fig. 3). Among sampling points variation it was observed that, in February and April water from sampling point 3 to 18 (Aminbazar to Sadarghat) showed high EC (800-1100 $\mu \mathrm{S} / \mathrm{cm}$ ) of water (Fig. 5). Sources of dissolved ions include soil and rocks in the watershed, wastewater from sewage treatment plants and urban runoff from roads. 


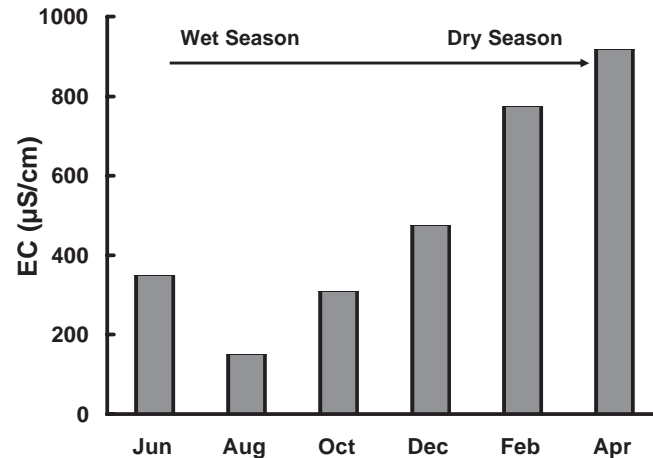

Fig.3 Average Electrical Conductivity in water of Buriganga River at different times of year.

In dry season various industrial and urban activities with low volume of water were the main cause of high EC level in river water.

On the other hand, EC of water was relatively low during wet season from June to October (109 to $498 \mu \mathrm{S} / \mathrm{cm}$ ) due to dilution effect (Fig. 3).

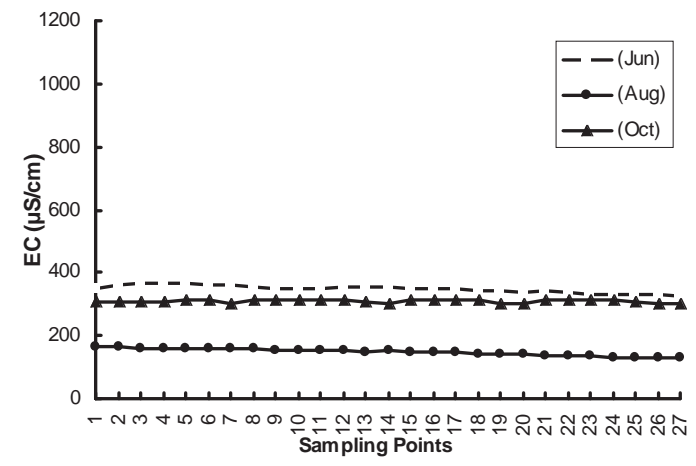

Fig.4 Electric Conductivity (EC) of water at different points of Buriganga river in June, August and October.

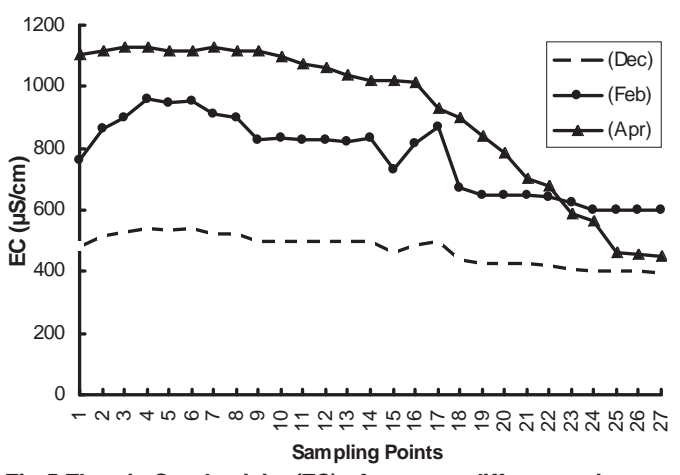

Fig.5 Electric Conductivity (EC) of water at different points of Buriganga river in December, February \& April.

The EC of water is an indicator of salinity and hazard gives the total salt concentration in water (Brady and Well, 2002). But all these EC values of water were within the permissible limit (Table I). So there was no harmful effect by salt concentration or salinity hazards in respect of EC.

Table I. Standards for water.

\begin{tabular}{l|c|c|c}
\hline Parameter & $\begin{array}{c}\text { Drinking } \\
\text { water }\end{array}$ & $\begin{array}{c}\text { Inland } \\
\text { surface water }\end{array}$ & $\begin{array}{c}\text { Irrigation } \\
\text { water }\end{array}$ \\
\hline Temp. ${ }^{\mathrm{O} C}$ & $20-30$ & 40 & $20-30$ \\
pH & $6.5-8.5$ & $6.0-9.0$ & $6.5-8.5$ \\
DO (mg/l) & 6 or more & $4.5-8.0$ & 5 or more \\
EC $(\mu \mathrm{S} / \mathrm{cm})$ & -- & 1200 & $700-3000$ \\
TDS $(\mathrm{mg} / \mathrm{l})$ & 1000 & 2100 & $450-2000$ \\
\hline
\end{tabular}

Source: Guide to the Environmental Conservation Act 1995 and Rules 1997.

The Total Dissolved Solid (TDS) concentration of river water was considerably high during dry season from December to April with average value in the range of 167 to $435 \mathrm{mg} / \mathrm{l}$ and the highest average TDS value of water found during the month of April (TDS = $435 \mathrm{mg} / \mathrm{l}$ ) (Fig. 6). Primary sources for elevated TDS level in river water are agricultural runoff, leaching of soil contamination and point source water pollution discharge from industrial and sewage treatment plants particularly during dry season with low water level.

On the other hand, the TDS was relatively low during wet season from June to October (50 to $80 \mathrm{mg} / \mathrm{l}$ ) due to dilution effect and the lowest average TDS value found in October (50 mg/l) (Fig. 6).

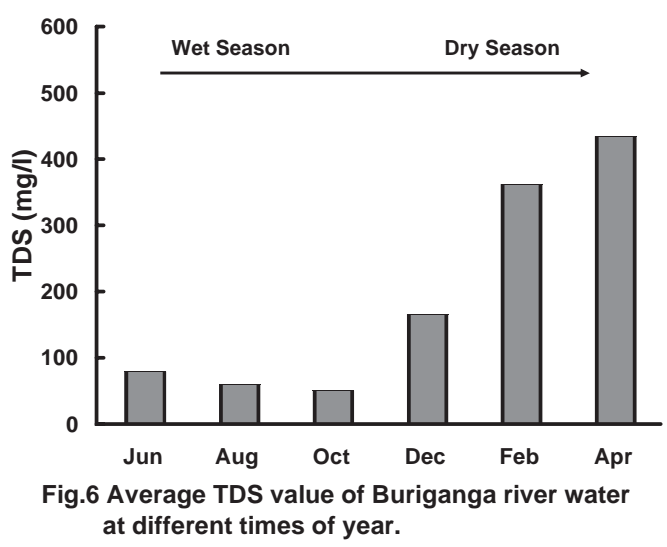

Among sampling points variation it was observed that, in February and April water from sampling point 4 to 17 (Mohammadpur to Sadarghat) showed high TDS of water (around 350-500 mg/l) due to huge urban and industrial activities around river (Fig. 7 and 8). 


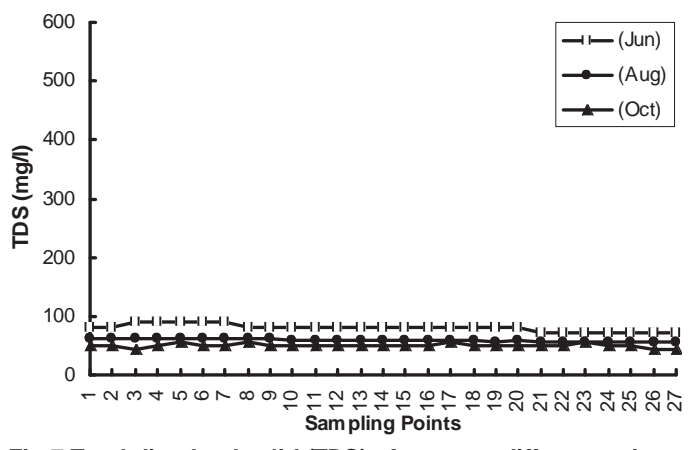

Fig.7 Total dissolved solid (TDS) of water at different points of Buriganga river in June, August and October.

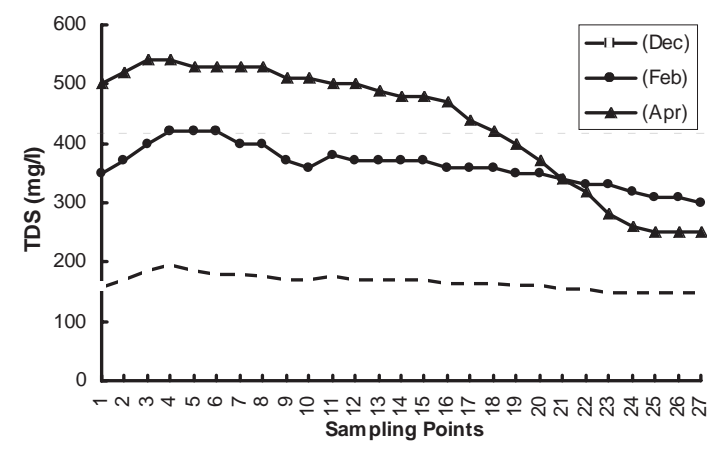

Fig.8 Total dissolved solid (TDS) of water at different points of Buriganga river in December, February and April.

But all these TDS values of water were within the permissible limit (Table I).

Dissolved oxygen (DO) concentration of water of Buriganga river was significantly low during dry season from December to April (average value in the range of 2.73 to $3.72 \mathrm{mg} / \mathrm{l}$ ) and the lowest average DO of water found during the month of February $(\mathrm{DO}=2.73 \mathrm{mg} / \mathrm{l})$ (Fig. 9).

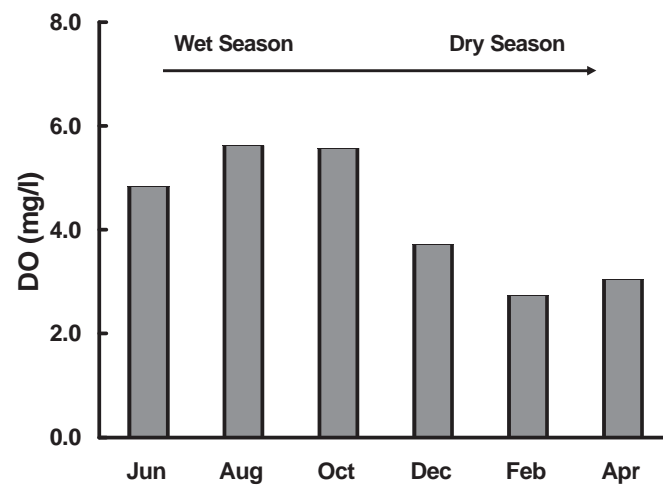

Fig.9 Average DO of water of Buriganga River at different times of year

This may be due to high organic and microbial activities with low volume of water during dry period. DO concentration of water was comparatively high during wet season from June to October with average value in the range of 4.84 to $5.59 \mathrm{mg} / \mathrm{l}$ (Fig. 9) due to dilution effect.

Among sampling points variation it was observed that, in February and April water from sample point 10 to 17 (near Hazaribagh, Kamrangirchar, Lalbagh, Sadarghat and Shutrapur areas) showed very low Dissolved Oxygen concentration of water (around $2.5 \mathrm{mg} / \mathrm{l}$ ) which was much lower than the permissible limit and in February and April water from sampling point 13 near Lalbagh showed the lowest DO concentration of water (DO = $2.20 \mathrm{mg} / \mathrm{l}$ ) (Fig. 11). High amount of organic wastes discharged from tannery, textile and dying industries into the river from those areas. Biodegradable organic wastes dumped into the river from fruits and vegetables wholesale depot near Sadargaht. These organic wastes reduce dissolved oxygen during decomposition by heterotrophic microorganisms.

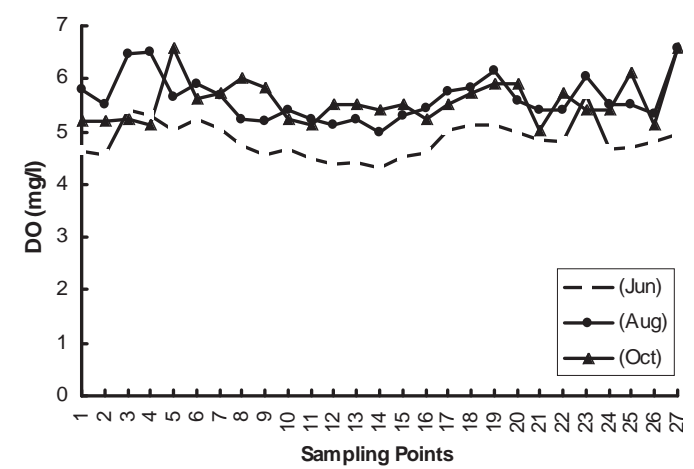

Fig.10 Dissolved Oxygen (DO) of water at different points of Buriganga river in June, August and October.

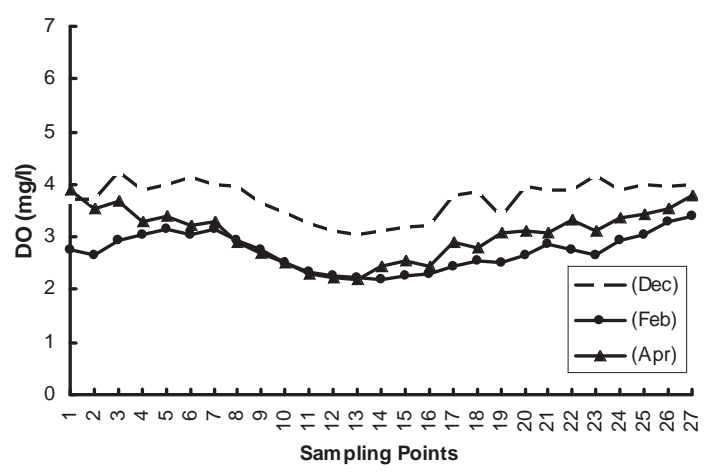

Fig.11 Dissolved Oxygen (DO) of water at different points of Buriganga river in December, February and April.

So the water of Buriganga river was relatively safe during wet season. But in dry season, water was not within the safe limit for drinking purpose, fisheries, irrigation and other activities in respect of DO concentration (Table I). The dissolved oxygen concentration of water of Buriganga river indicated an unfavorable environment for aquatic lives during dry season. 


\section{Cationic composition}

In the study area, concentration of basic cations: Sodium $(\mathrm{Na})$, Potassium (K), Calcium (Ca), Magnesium (Mg) and Ammonium $\left(\mathrm{NH}_{4}^{+}\right)$were high during dry season from December to April. Inversely concentrations of these cations were comparatively low water during wet season (June to October). Concentration of $\mathrm{Na}, \mathrm{K}, \mathrm{Ca}, \mathrm{Mg}$ and $\mathrm{NH}_{4}{ }^{+}$were ranged from 9.4 to $39.3 \mathrm{mg} / \mathrm{l}, 4.2$ to $10.6 \mathrm{mg} / \mathrm{l}, 17.2$ to 34.0 $\mathrm{mg} / \mathrm{l}, 6.4$ to $22.7 \mathrm{mg} / \mathrm{l}$, and 4.9 to $14.4 \mathrm{mg} / \mathrm{l}$ respectively (Table II and Fig. 12). and 14) which was higher than the permissible limit (Table II). High amount of organic wastes discharged into the river from various tannery, textile and dying industries of those areas. These organic wastes increased ammonium concentration in water through decomposition. Agricultural runoff also increased ammonium concentration in river.

\section{Anionic composition}

In the study area, concentration of basic anions: Nitrate $\left(\mathrm{NO}_{3}^{-}\right)$, Bicarbonate $\left(\mathrm{HCO}_{3}^{-}\right)$, Chloride $\left(\mathrm{Cl}^{-}\right)$, Phosphate $\left(\mathrm{PO}_{4}{ }^{3-}\right)$ and Sulfate $\left(\mathrm{SO}_{4}{ }^{2-}\right)$ were high during dry season

Table II. Concentration of cations at different times of year in Buriganga river.

\begin{tabular}{l|c|c|c|c|c}
\hline \multicolumn{7}{c}{ Concentration (mg/l) } \\
\hline Months & $\begin{array}{c}\text { Sodium } \\
\left(\mathrm{Na}^{+}\right)\end{array}$ & $\begin{array}{c}\text { Potassium } \\
\left(\mathrm{K}^{+}\right)\end{array}$ & $\begin{array}{c}\text { Calcium } \\
\left(\mathrm{Ca}^{2+}\right)\end{array}$ & $\begin{array}{c}\text { Magnesium } \\
\left(\mathrm{Mg}^{2+}\right)\end{array}$ & $\begin{array}{c}\text { Ammonium } \\
\left(\mathrm{NH}_{4}^{+}\right)\end{array}$ \\
\hline June & 10.9 & 5.2 & 20.1 & 9.8 & 5.2 \\
August & 9.4 & 4.2 & 17.2 & 6.4 & 4.9 \\
October & 10.2 & 4.8 & 19.2 & 7.2 & 5.1 \\
December & 12.3 & 6.4 & 23.9 & 13.5 & 9.0 \\
February & 24.6 & 10.6 & 32.6 & 22.7 & 14.4 \\
April & 39.3 & 10.5 & 34.0 & 22.6 & 13.6 \\
DoE Standard & 200.0 & 12.0 & 75.0 & $30-35$ & 0.5 \\
\hline
\end{tabular}

DoE (Department of Environment), 1997

All these cations were within the safe limit except Ammonium (Table II).

Among sampling points variation it was observed that, in February and April water from sampling point 3 to 19 near Lalbagh, Hazaribagh kotouali, Sadarghat and Shampur areas showed high $\mathrm{NH}_{4}^{+}$conc. in water (around $14 \mathrm{mg} / \mathrm{l}$ ) (Fig. 13 from December to April. Inversely concentrations of these anions were comparatively low water during wet season (June to October). Concentration of $\mathrm{NO}_{3}^{-}, \mathrm{HCO}_{3}{ }^{-}, \mathrm{Cl}^{-}, \mathrm{PO}_{4}{ }^{3-}$ and $\mathrm{SO}_{4}{ }^{2-}$ were ranged from 12.9 to $34.5 \mathrm{mg} / \mathrm{l}, 37.9$ to 143.2 $\mathrm{mg} / \mathrm{l}, 39.6$ to $98.3 \mathrm{mg} / \mathrm{l}, 1.7$ to $6.1 \mathrm{mg} / \mathrm{l}$, and 2.0 to $9.8 \mathrm{mg} / \mathrm{l}$ respectively (Table III and Fig. 15). 
All these anions were within the safe limit except Nitrate $\left(\mathrm{NO}_{3}{ }^{-}\right)$and Phosphate $\left(\mathrm{PO}_{4}^{3-}\right)$ (Table III).

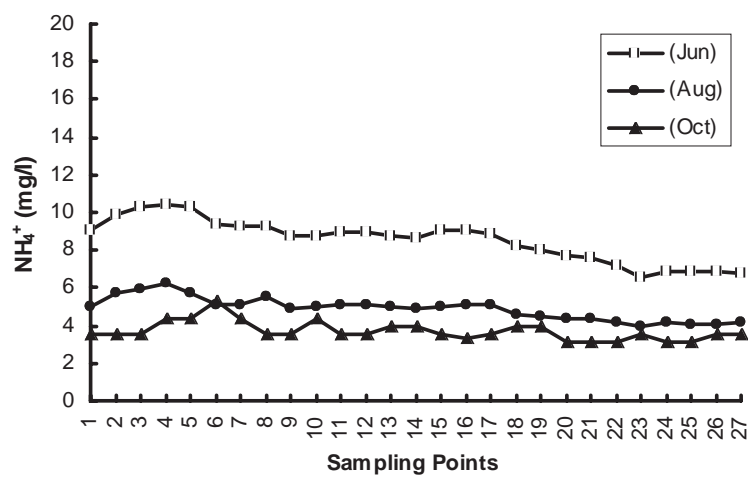

Fig.13 Ammonium $\left(\mathrm{NH}_{4}^{+}\right)$con. of water at different points of Buriganga river in June, August and October.

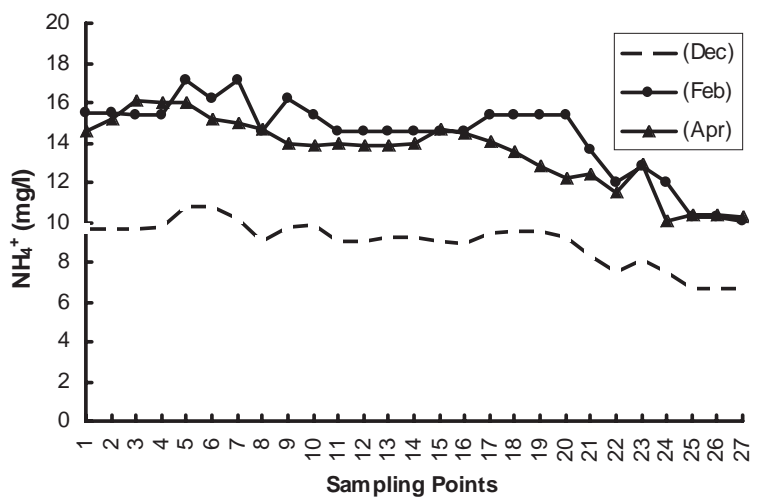

Fig.14 Ammonium $\left(\mathrm{NH}_{4}^{+}\right)$con. of water at different points of Buriganga river in December, February and April.
Among sampling points variation it was observed that, in February and April water from all sampling points showed high $\mathrm{NO}_{3}{ }^{-}$concentration (Fig 16 and 17).

Effluents discharged from tannery, textile and other manufacturing industries into the river, contain high amount of nitrate. Agricultural run-off from fertilizers and manure also contain nitrates. Agricultural run-off from fertilizers and manure, containing nitrates and phosphates, and discharge of partially treated or untreated sewage being major causes of eutrophication in river (Henderson, 1987). Except some points in August and October the nitrate concentration of Buriganga river was higher than the permissible limit (Table III) throughout the year. So water of Buriganga river has nitrate pollution especially during dry season.

Table III. Concentration of anions at different times of year in Buriganga river

\begin{tabular}{l|c|c|c|c|c}
\hline \multicolumn{7}{c}{ Concentration (mg/l) } \\
\hline Months & $\begin{array}{c}\text { Nitrate } \\
\left(\mathrm{NO}_{3}{ }^{-}\right)\end{array}$ & $\begin{array}{c}\text { Bicarbonate } \\
\left(\mathrm{HCO}_{3}{ }^{-}\right)\end{array}$ & $\begin{array}{c}\text { Chloride } \\
\left(\mathrm{Cl}^{-}\right)\end{array}$ & $\begin{array}{c}\text { Phosphate } \\
\left(\mathrm{PO}_{4}{ }^{3-}\right)\end{array}$ & $\begin{array}{c}\text { Sulfate } \\
\left(\mathrm{SO}_{4}{ }^{2-}\right)\end{array}$ \\
\hline June & 14.6 & 59.4 & 52.5 & 2.2 & 5.6 \\
August & 12.9 & 37.9 & 39.6 & 1.7 & 2.0 \\
October & 13.5 & 43.2 & 42.1 & 2.1 & 2.1 \\
December & 20.4 & 98.0 & 57.1 & 3.8 & 3.1 \\
February & 33.3 & 143.2 & 94.4 & 6.0 & 5.1 \\
April & 34.5 & 113.4 & 98.3 & 6.1 & 9.8 \\
DoE Standard & 10.0 & 150.0 & $150-600$ & 6.0 & 400.0 \\
\hline
\end{tabular}

DoE (Department of Environment), 1997 


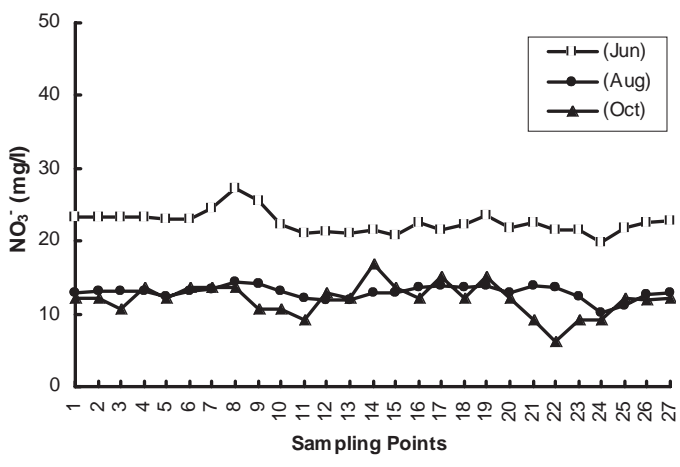

Fig.16 Nitrate $\left(\mathrm{NO}_{3}{ }^{-}\right)$of water at different points of Buriganga river in December, February and April.

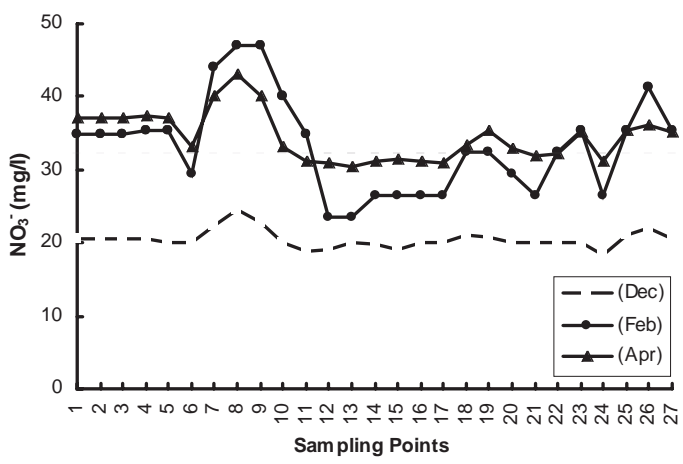

Fig.17 Nitrate $\left(\mathrm{NO}_{3}{ }^{-}\right)$of water at different points of Buriganga river in June, August and October.

\section{Conclusion}

From above discussion it was observed that, the physiochemical properties such as Temperature, $\mathrm{pH}$, EC, TDS were within the safe limit through out the year. But Dissolved Oxygen concentration in dry season was very low due to various microbial activities and it creates an unfavorable environment for aquatic lives.

Ion concentration (both cations and anions) of Buriganga river water was relatively by low during wet season due to dilution effect and concentration was high in dry season due to diverse industrial and urban activities in low water level condition. High concentration of nitrate, phosphate, ammonium and organic wastes creates eutrophication problem in Buriganga river.

In dry season the level of pollution was much higher than in wet season. Thus Buriganga river water was not safe for drinking purposes, irrigation, fisheries, and various industrial uses for most of the times of year.

\section{Acknowledgement}

The authors are grateful to the Director, BCSIR Laboratories, Dhaka for his co-operation and help for providing laboratory facilities during this research work.

\section{Reference}

Ahmed A. U. and Reazuddin (2000) Industrial Pollution of Water Systems in Bangladesh, University Press Limited, Dhaka, Bangladesh pp 175-178.

Brady N. C. and Well R. R. (2002) The Nature and Properties of Soils. 12th ed. Pearson Education, Inc. New Delhi, India. pp. 261-269.

De A. K. (1989) Environmental Chemistry. Wiley Eastern Ltd., New Delhi, India. pp. 42-43.

DoE (1997) Bangladesh Gazette, No. DA-1. Department Of Environment, Ministry of Forest. pp. 1324-1327.

Guide to the Environmental Conservation Act (1995) and Rules (1997). Bangladesh centre for advanced studies. pp: 204-222.

Gupta P. K. (2000) Methods in Environmental Analysis: Water, Soil and Air. Agrobios, Jodhpur, India. pp. 5-76

Henderson S. B. (1987) Decaying Lakes. John Wiley \& Sons Ltd. Great Britain.

Hunt J. (1981) Determination of Total Sulfur in Small Amount of Plant Material. Anal. 105: 83-85.

Jackson M. L. (1967) Soil Chemical Analysis, Prentice Hall, Inc. Englewood Cliffs, N. J. USA. pp. 227-261.

Lanyon L. E. and Heald W. R. (1982) Magnesium, Calcium, Strontium and Barium. In: Page, A. L., R. H. Miller and D. R. Keeney (eds.). Methods of Soil Analysis. Part 2. 2nd ed. Madison, Wisconsin USA. pp. 252- 257

Murphy J. and Riley, J. P. (1962.) A Modified Single Solution Method for the Determination of Phosphate in Natural Waters. Anal. Chim. Acta. 22: 481-483.

Sarker M. A. K. (2005) Study on the Accumulation And Seasonal Variation of Trace Metals In Water, Sediment and Some Fishes of the Buriganga River. M Sc thesis (1998-1999), Department of Zoology, Dhaka University, Dhaka, Bangladesh. pp. 1-4.

Todd D. K. (1980) Ground Water Hydrology. Jhon Willy and Sons. Inc., New York.

Received : October 12, 2008;

Accepted : February 17, 2009 